\title{
BLIND SERBIAN RULERS AND FAMOUS PERSONS
}

\author{
Janicijevic Katarina, ${ }^{1}$ Kocic Sanja, ${ }^{1}$ Radovanovic Snezana, ${ }^{1}$ Sarenac Vulovic Tatjana, ${ }^{1,2}$ \\ Petrovic Nenad, ${ }^{1,2}$ Todorovic Dusan ${ }^{1,2}$ \\ ${ }^{1}$ Faculty of Medical Sciences, University of Kragujevac, Serbia \\ ${ }^{2}$ Clinic of Ophthalmology, Clinical Centre of Kragujevac, Serbia
}

Primljen/Received 01. 09. 2016. god.

Abstract: History and medicine were an integral part of life-being of blind serbian acters. One of the main actors was half-blind serbian ruler, Stefan of Decani and whose name was associated with first ophthalmologic hospital and precursor of the eye's injuries care. After, national reputation as Stefan Blind Righteous, ruler of the Serbian despot between 1458. and 1459. (member of Brankovic's dinasty), and he was blinded by eye injuries burns. The famous national was also Filip Visnjic, as blind minstrel and authentic creator of serbian folk traditions, with sequels as a child, by bilateral infective panuveitis.

Keywords: serbian's history, blind personality, medicine, Stefan Decanski, Stefan Brankovic, Filip Visnjic.

\section{INTRODUCTION}

Authors looked through domestic historical references in proposed future research and challenges and the connection between Serbian history and blindness (caused by personal injuries or diseases of the eye). Authors have analyzed the aspects of war-interest known, of blind Serbian rulers and historical figures, through the results of their injuries or diseases of the eye.

Do you, for example, believe that Serbian history has properly recognized the importance of people (rulers, poets) who were deprived of sight? Or do you think that blindness of certain people had an impact on decision-making or events important for Serbian history and medicine? These and similar questions are left to readers that they themselves have to try to find possible answers.

The significance of this work certainly has a clear meaning, given the historical and/or medical context. The most well-known facts, set of analysis and set goal of this paper is hopefully reached in part through the efforts of all authors.
Prihvaćen/Accepted 05. 10. 2016. god.

The aim of this study was to draw attention to the problem of blindness in important people throughout our history and medicine. Original thought is that perhaps we are not always aware of how important people in our history and church were blind, but still performed some of their life's work at the nation's best and now deserves more attention.

\section{STEFAN DECANSKI - SERBIAN HISTORICAL RULER}

The domestic history scene and the ophthalmic pathology were presented through the first of the three epoch-making historical figures. St. King Stefan of Decani was one of the best known Saints of the Serbian Orthodox Church. He was born as the oldest son of the saintly King Stefan Uros II Milutin and his wife Elizabeta, a Hungarian princess. Living at the court of his parents, and as the heir-apparent, he received good education, exercised studying of the languages and writings of Serbian people, and so his heart strengthened by study of the Holy Scripture, and the teachings of the Orthodox Faith. Since he was the half-blind, and the first ophthalmologic hospital for the eye injuries in Serbia, maybe took his name (it is assumed). Saint King Stefan Uros III Decanski was born about 1276, and died in Zvecane $11^{\text {th }}$ of November 1331. He was the King of Serbia from Nemanjic family (1331-1346), the son of King Milutin (1282-1321), and later through the history, his son Dusan, the Mighty became the king (Emperor from 1346-1355) (1).

Wearing the black blindfold after the burns of both eyes, he was faithfully learning about his own (eye injuries, burns) and the other eye problems in Constantinople, and shared his knowledge, returning to Serbia. He continued expanding Serbia on account of the Byzantine Empire and created from it, the most power- 


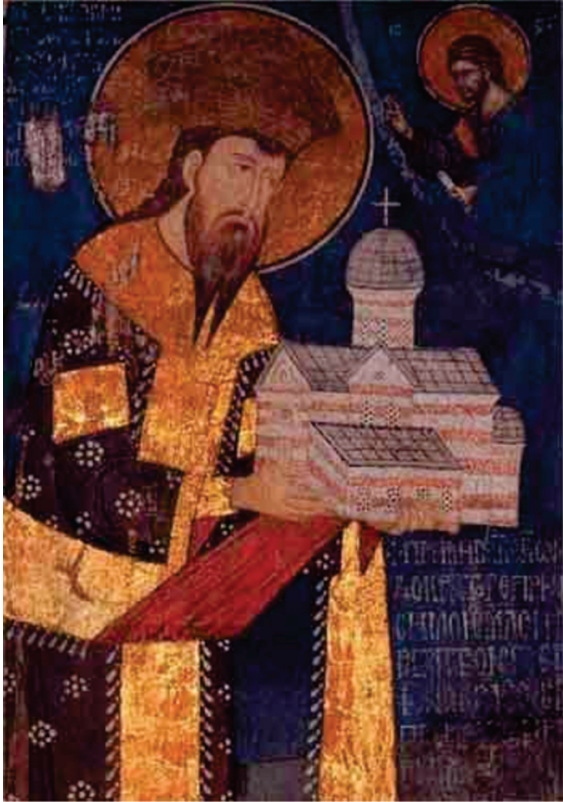

Figure 1. St. King Stefan of Decani; Original source: The fresco in Decani Monastery, Stefan with church model, in $14^{\text {th }}$ century

ful force in Balkan. His military force won at Velbuzd in 1330th, so Serbian Orthodox Church canonized him as a holy king. Monestary Decani, under Prokletija was the Stefan's foundation (Figure 1).

His father blinded him in 1310, because of his revolting, and then sent him to the monastery of Christ Pantocrator, which was also forerunner of the hospital for the treatment of blinds. He ruled from 1321-1331, when he was over from the throne in the civil war by his son Dusan. Foreign sources said that he had been strangled by Dusan. He was executed in the tomb, which he raised on the south side of the nave in Visoki Decani of Kosovo. After the vision of a monk's tomb was opened and found his body incorrupt and the relics placed in the casket and now it can be found in the monastery. His cult, born during his life; it was followed by blind people in that time. His title "saint emperor" was found for the first time on the one cross in 1330, and it was kept in its endowment. Bulgarians during the First World War took his body, but after that, they had to return it (2).

Archbishop Danilo II, in literary work "Lives of the Serbian kings and archbishops" wrote, that Milutin's son had offered to negotiate, and that Stefan moved by this act, he went to his father and begged him for his forgiveness. When Milutin put hands on Stefan, he had no mercy. Stefan was shackled and sent to Skopje where he was blinded, and later sent off to Constantinople. Stefan, in the fear of his father, wore the black blindfold almost for the rest of his life. He was only partially blinded, with a hot iron. He removed it many years later in his reign.
In Istanbul, former ruler of that time the Emperor Andronicus had sympathy for the young and sacrificed prince, because of death of his own young son. So, he didn't want to make his miserable fate even worse (2).

The death of Stefan, half-blind Serbian giants was linked to the legend of the curse of Dusan's descendants and later the entire Serbian state. Stefan, when they came to kill him, cursed his son and his descendants. Although, the curse did not fur field on the son, it fell on his grandson Uros, who lost all military kingdom. This legend has lasted for many centuries, and they all remembered the curse, when Emperor Lazar with his warriors felt in Kosovo and Serbia felt under the Turks (3).

Serbian medieval medicine had the characteristics as western medicine of those times in terms of practical medical science, whereas the ancillary medical branches were under Byzantine influence. Besides the compositions of Christ's miracles and paraboles were underlying part of the fresco-painting, the scenes of Christ's miraculous recoveries had an important place in the Christian iconography of the New Testament events. One of the most impressive cycles of Christ's miracles in the Serbian and Byzantine medieval art was painted in 1340, in the church dedicated to the Ascension of Lord Christ at Decani Monastery (constructed between 1327 and 1335). A considerable number of 22 frescoes of different artistic value and technique displayed the miraculous recovery of patients afflicted by various chronic ailments: handicapped - as blind, lame and deaf, and paralytics, lepers, etc (4). The King Stefan Uros Decanski III founded the hospital in the Decani Monastery, as a purely medical institution for providing treatment. This hospital was organized and modeled by the hospital in Pantocrator Monastery in Constantinople. His biographer Gregory Camblak described that this hospital took patients suffering from epilepsy and serious nervous disorders, lepers, cripples, paralytics and the eye diseases (the injuries) (4). This was supported as the certain that masters painted even some of patients from Monastery Hospital.

The scenes of Christ's miraculous recovery in the Decani Monastery were undoubtedly significant for both: the military history and the Serbian medieval medicine. This considerable cycle of the monumental painting and frescoes with medical matter, constituted the basis for research of the Serbian medicine of the Middle-Ages. Today, as the Serbian people suffer through another turbulent chapter in their history, they would do well to have on mind such exemplary character of their Martyred King Stefan Uros III (Decanski) $(4,5)$. He was crowned 6 January 1322 by the Archbishop of Serbia as Stefan Uros III Decanski, King of Serbia. In 1323, he defeated and killed his half-brother Konstan- 
tin, retaking of Zeta (5). Having in the true Christian manner endured the grievous trials and afflictions which he met through the years, the King deserved to live out the rest of his life in peace. But, it was only fitting that he who suffered as martyr in life should be granted an opportunity to receive in death a martyr's crown. Dusan's successes on the field of battle had given him the appetite for power and glory, and encouraged by his entourage of nobles, so he decided to hasten his father's death. St. Stefan was taken to prison to a fortress in the town of Zvecan and cruelly murdered (by some data he was hung, according to another he was strangled) $(6,7,8)$.

Dusan earnestly and tearfully repented of his treachery, and the next year, on the feast of the Holy Apostles, Petar and Pavle, he had his father's remains transferred from Zvecan to Decani, where they were placed in the marble tomb. In 1339 the tomb was opened, and his body was found to be incorrupt. On that day people saw many miracles of the healing: especially that the holy king proved to heal diseases and injuries of the eye, and at his relics blind people received their sight $(9,10,11)$. The medical analysis of illnesses and causes of death of Serbian rulers in the Middle-Ages was difficult. King Stefan Uros II Milutin (1282-1321) died as a seventy years old man. His biographer, Archbishop of Pec, Danilo II wrote about a sudden onset of the disease. King Milutin was paralyzed and aphasic. In the terminal stage, he was unconscious and insensible (12).

The first written Serbian medical records could be found in the Middle Ages (XIII century) when the Serbian state was very well organized. St. Save was the son of Grand Prince Stefan Nemanja (1171-1196), founder of the Serbian independent state and of the powerful dynasty that ruled Serbia for two centuries. At that time, the first hospital service was established, as well as the social program which regulated the relationship between marriage and family, and the kind of therapy, under the church and state control (13). The famous Hylandar place was perhaps the first of Medical Codex as the most famous reminder of Serbian medical sciences (14). The enviable level of health culture and social care of the ill and debilitated people of the Serbian medieval state was far advanced for that time $(15,16,17)$. Favorable conditions for the development of medieval medicine was linked with the arrival of the Nemanjic's dynasty to the throne of the Serbian medieval state, i.e. Stefan Nemanja, and later with the life and work of his son Prince Rastko Nemanjic - Saint Sava $(18,19)$. The wide field of activity of the Grand Prince Stefan Nemanja included the creation of stable and independent state with the significant and shrewd political activity, building of churches, defender of the Orthodox Christianity, foundation of the first Serbian hospital outside of borders of Serbian, state in Hylandar monastery $(20,21)$.

\section{ST. STEFAN BRANKOVIC - SERBIAN DESPOT}

St. Stefan Branković was righteous descendant of the glorious Serbian Prince Lazar, of the Great Kosovo. Lazar and Milica had the oldest daughter Mara, who married for Serbian nobles, Vuk Brankovic. Vuk and Mara had three sons: Grgur, Djuradj and Lazar. After the death of Lazar and Milica, their son Stefan High (from 1389 until 1427) married the Greek princess Irina (Jelena) Paleologovom of Thessaloniki. Djuradj and Jelena had many children and among them was born the Blessed Stefan (about 1417 years). In his childhood, Stefan was blessed in every good mannered: he gained a great intellect and piety, obedience to parents, so that faith, wisdom and courage of many overcame, and its natural physical beauty. But the most important features Blessed Stefan lied in his commitment to the will of God, pure life and fidelity to the Church and the Orthodox faith. When the Turks attacked the capital of Smederevo, Grgur was captured and taken to Adrianople, where they were, on the orders of the Sultan Murat, and without knowledge of sister Sultana Mara, cruel both blinded by the Turks, on Easter Sunday in 1441. The one of the main reasons for this blindness of Serbian nobles was turkey envy, for their beauty and chivalry and fear that they did not become

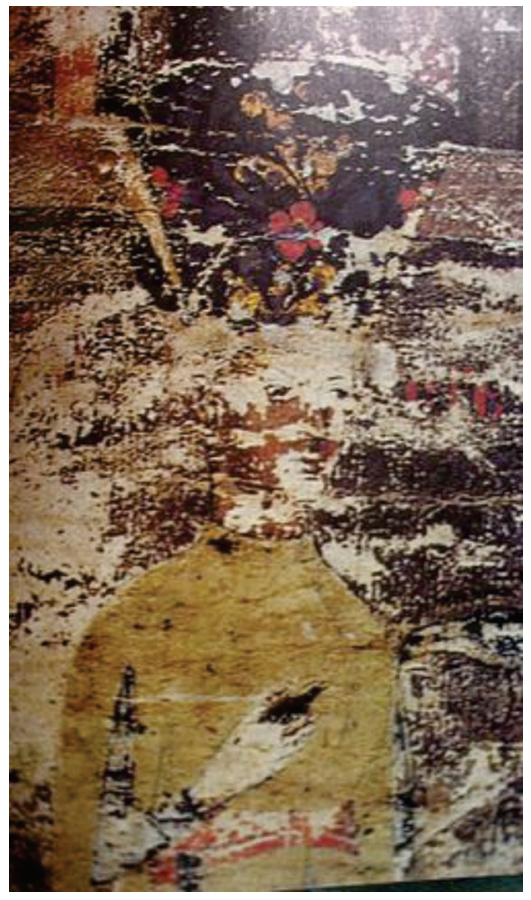

Figure 2. Righteous Blind Stefan, St. Serbian Despot Brankovic; Original source: The fresco of the young Stefan Esfigmenske Charter, in 1429 
heirs and Serbian rulers of the country. A few years after the suffering of the innocent, blissful and much suffering Stefan sighted and blinded his brother Gregory.

Sultan Murat returned to Serbia and lived surrender father despot Giurgiu. Turks were forced to make peace and to return to live despot Giurgiu's sons, and the entire city of Smederevo and despotism. Sadly was the scene when they met the blind father and his children: children went into the arms of his father, but the old despot roared like a wounded lion and tumbled to the ground unconscious. The old father died on Christmas Eve, $24^{\text {th }}$ December 1456 , in ninety years of life, and soon after his death, and the death of his wife Jerina, Stefan's mother (3sr May 1457), and soon after her young despot Lazar $\left(20^{\text {th }}\right.$ January 1458$)$. Then, if desired Serbian people and the nobles, and the blessing of Serbian Patriarch, blessed Blind Stefan enthroned in Smederevo for the new Serbian Despot (Figure 2).

As the ruler he was awarded the wisdom and courage, because it was very difficult time and occasions managed to preserve the Serbian country and people and not to hand over the city of Smederevo (not the Turks, nor the Hungarians). Innocent righteous Blind Stefan, the last legitimate Serbian ruler would then be expelled from the homeland, and he would have the big troubles. However, in his unjust exile from the homeland, Smederevo immediately fell of the Turks ( $20^{\text {th }}$ June 1458), and so the punishment of God came upon Serbian's land (22). Righteous Stefan and his wife Angelina stayed with their children and lived a peaceful life devoted to the Orthodox Church, although it was not easy in that time and in the middle of the Latin and Papal countries. Stephan with his family lived in Serbia in the humility and privation, sometimes receiving alms from many sides. He died on $9^{\text {th }}$ October 1476, and his holy body was buried in Belgrade, on Furlandi. In 1688, the relics of St. Stefan (with relics of other Brankovic) had put away for some time in St. Andrew, but soon returned to Krusedol, when rested peacefully until Turks put into pieces, and together with the church burned of Krusedol in 1716. From that fire, stated only some and smaller parts, including the right foot, as holy and righteous Blind Stefan as martyrs and victims of many Serbians. Grgur and Stefan were blinded (the burns) by the Sultan Murat II, of 1441 in Tokat fortress by the sea and near to Istanbul, in an old mansion called "Bedevi Cardak". They were blinded with hot iron over the eyes (burns). Stefan's brother, Blind Gregory, after the conquering the city of Smederevo by Turks $\left(20^{\text {th }}\right.$ June 1459) retreated to monastery Hylandar, where he passed away as a German monk (in late 1459). The relics of Stefan Blind based at the monastery of Krusedol, which was endowed by his son, Maxim. Stefan
Blind, as New Brankovic and despot ruled only a year in the mid of XV century. His body wasn't falling apart, after which he transferred the relics to the monastery, probably 1515. Stefan Brankovic (born - 1417, died $-9^{\text {th }}$ October 1476 in Belgrade, it was a fortress in present-day - Italy), also known in historiography as Stefan Blind was briefly the despot (ruler) of the Serbian Despotate, between 1458 and 1459 as a member of the Brankovic dynasty. On $11^{\text {th }}$ September 1429 , Djuradj made donation to Esphigmenou Monastery at Mount Athos. The charter for the document named by his wife Eirene and five children. The MaĐpard -sarelli manuscript also named by the same five children of Djuradj and Eirene. Other genealogies mentioned a sixth child - Todor Brankovic. The 1429 document mentioned him with the title of Despot. Grgur was appointed governor of territories of southern Serbia associated to House of Brankovic. He was reportedly appointed by Murat II of the Ottoman Empire in 1439. In April 1441, Grgur was accused of plotting against Murat and his governorship terminated. He was imprisoned in Amasya and blinded on $8^{\text {th }}$ May 1441. The Massarelli manuscript mentioned Grgur as unwed. Later genealogies name his wife as "Jelisaveta". Vuk Grgurevic, a son of Grgur, was later a titular Serbian despot (1471-1485). Both blind brothers seem to be omitted from considerations as possible heirs to their father. They could only claim the throne in 1458 , since the death of Lazar leaving them the only male representatives of the Brankovic. When Serbian Despotate had been lost to Ottomans, Stefan's son Jovan of Serbian refugees to Kingdom of Hungary. There Jovan was finally recognized as Serbian Despot, with a principality called Raitzen (23). He was venerated as Saint Stefan Blind by the Serbian Orthodox Church. He long after that his body would be published as incorrupt, and so what is the tomb began to appear a marvelous heavenly light. The brightness of the first saw some guys were thieves who came to rob his grave. When they turned then to open his tomb, his body was found incorrupt and even, together with decomposed his suit. From its many holy relics then got healing, and many blind received their sight (24). Serbian Orthodox Church today celebrates St. Stefan's (1425-1476), despot of Serbian who did not want at any price and became Turkish vassal renounced Serbianism, who died in Udine (Italy) in the greatest misery (25). Turks to Stefan blinded, thinking that this would weaken the Serbian government, and that the Serbs would have to respecting to the leader who had a disability. However, Stefan Blind was shown as "tough nut" that was willing to cooperate and only the Hungarians resisted the Turks. Stefan immediately after the entry into throne managed to preserve Smede- 
revo from Turks led by Mehmed II Conqueror. After the successful defense of Smederevo, many foreign powers have intervened, but not for the sake of defending the interests of Serbia, but for fear of Ottoman Turks coming to their doorstep (26).

"Opinions about the rule of despot Stefan blind today are divided. Some believe that he never should take charge, while others think it was the last ruler who then sincerely defended Serbia from the Turks. Serbian Church has never forgotten the role of the ruler who was given the title of saint. Stefan Blind was remembered as the person, who strongly believed that Orthodoxy was the only thing that could have saved Serbians, throughout the Turkish invasion" (27).

\section{FILIP VISNJIC - SERBIAN HISTORICAL MINSTREL}

Another historical and national character, Filip Visnjic (1767-1834), was one of the most famous Serbian minstrels and authentic creator of Serbian folk songs and traditions. He was born in Majevica, at village of Gornja Trnova in Ugljevik. As he turned blind after being sick from smallpox and the sequels as a child by panuveitis (complicata), he had become a professional Serbian singer with old fiddle in hand he traveled throughout the Bosnian pashadom. At the monastery councils he sang for Serbs, and passing through the towns narrated in the courts of the Turkish rulers. Two audiences were looking for different poems, so Visnjic had two different repertoires, one for the Christian and the other for the Muslim audience (28). His poems about Saint Sava were characteristic of the monastery, hagiographic repertory of total blind singer. Filip Visnjic was the creator of new poems. Thirteen poems "Karadjordje's time" along with several other less important poems of other poets make the last and insurrectionary cycle of Serbian folk epics. The most important moment in the life of Filip Visnjic was his move to Serbia in 1809. Direct contact with the insurrectionist events was the moment of his birth as the famous Serbian and military poet. After the collapse of the First Serbian Uprising, Visnjic has moved to Srem and settled in the village Grk, now Visnjicevo. Main place occupied the Serbian rebel poems, which he sang by himself (28). In monastery Sisatovac in 1815, he met Vuk Karadzic, who had written seventeen of his songs, four old and thirteen new poems. In Sisatovac, Filip Visnjic had often been the guest at then leading Serbian poet and famous person to Lucian Musicki. To these meetings of "Serbian Homer" and "Serbian Horace" authors owed information about Visnjic's life and work. Musicki told how he had created the songs: he asked the warriors when they returned from battlefield which was in

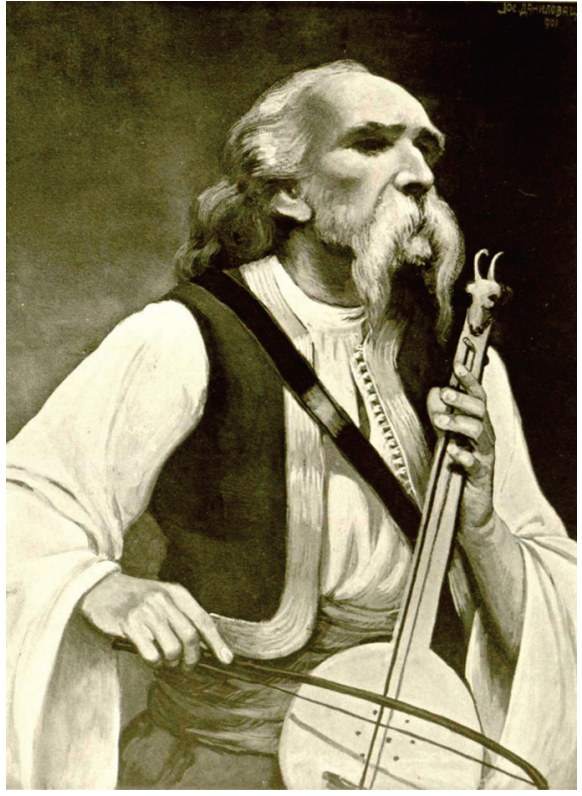

Figure 3. Filip Visnjic as blind serbian minstrel end historical poet; Original source: The grafic portrait of Josip Danilovac of Eminent Serbs in XIX century of Zagreb, in 1901.

head, where they were beaten, who died, against whom they were going. Songs from the first group were more artistically built, mainly "Start uprising against Dahias" and the first part of the song "The Battle of Misar", while in the second group the songs of value and importance of Ivo Knezevic. With his liberation enthusiasm Visnjic was most similar to Petar Petrovic Njegos (II), with whom he was bound trough the number of common features (29). Although he worked in the traditional framework of national epics served by standard formulas and cliches, he had largely outgrown the boxes and in the best moments of the epics made a new type of rebellion, liberation, revolutionary songs, with the strong individual and blind Serbian feature (30). With completely blind Serbian minstrel and poet, the great Serbian folk words trough heroic poems have recorded epochal Serbian history, art, culture and medicine traditions (Figure 3).

\section{CONCLUSION}

It should be noted that the Serbian historical and medical scenes from the perspective of the eye injuries and the eye diseases of the blindness, has not been fully understood by now. However, with the attitude towards the critical ophthalmic thinking, we are on the right path in shedding the light on the new discoveries.

\section{Conflict of interest}

The authors declare that there is no conflict of interest. 


\section{Sažetak}

\section{SLEPI SRPSKI VLADARI I ČUVENE LIČNOSTI}

Janicijevic Katarina, Kocic Sanja, ${ }^{1}$ Radovanovic Snezana, ${ }^{1}$ Sarenac Vulovic Tatjana, ${ }^{1,2}$ Petrovic Nenad, ${ }^{1,2}$ Todorovic Dusan ${ }^{1,2}$

${ }^{1}$ Faculty of Medical Sciences, University of Kragujevac, Serbia

${ }^{2}$ Clinic of Ophthalmology, Clinical Centre of Kragujevac, Serbia

Istorija i medicina predstavljaju sastavni deo bivstvovanja slepih srpskih aktera. Jedan od glavnih aktera je poluslepi srpski vladar, Stefan Dečanski, čije je ime povezano sa možda, prvom očnom bolnicom, kao pretečom za zbrinjavanje povreda oka, opekotina. Po nacionalnom čuvenju, Stefan Slepi Pravedni, bio je vladar Srpske despotovine između 1458. i 1459. (član

\section{REFERENCES}

1. Veselinović A, Ljušić RR. Srpske dinastije. Beograd: Službeni glasink Publ, 2008.

2. Živković T. Portreti srpskih vladara (IX-XII vek). Beograd: Zavod za udžbenike Publ, 2006.

3. Ćorović V. Istorija Srba. Beograd: Neven Publ, 2012.

4. Jović N, Jancić-Stefanović J. Miraculous recoveries in the frescoes of the Decani Monastery. Srp Arh Celok Lek. 1999; 127(7-8): 291-6.

5. Fajfarić Ž. Sveta loza Stefana Nemanje. Sremska Mitrovica: Tabernakl Publ, 2007.

6. Lopandić D. Letopis velikih župana. Istorijska hronika Srbije u veku Stefana Nemanje. Beograd: Narodna knjiga - Alfa Publ, 2004.

7. Blagojević M, Vitezović M, Matić M. Vekovi Srba-Srbi, srpske države i zemlje. Gornji Milanovac: Dečje novine Publ, 1997.

8. Mileusnić S. Danilo II, Life of Saintly Stefan Dečanski (after 1331). Medieval monasteries of Serbia Prometej Publ, 1994.

9. Fine JVA. The Late Medieval Balkans: A Critical Survey from the Late Twelfth Century to the Ottoman Conquest. University of Michigan Press Publ, 1994.

10. Sedlar JW. East Central Europe in the Middle Ages, 1000-1500. University of Washington Press Publ, 2015.

11. Pajović M. Vladari srpskih zemalja. Podgorica: Biblioteka Istorija Gramatik Publ, 2004.

12. Jovitsh N, Jovitsh J. Stroke as a probable cause of death in some Serbian medieval rulers. Srp Arh Celok Lek. 1995; 123(11-12): 323-7.

13. Pavlovic B, Dragovic S. Sveti Sava zacetnik stacionarne adravstvene zastite, socijalnog staranja i medicinskog obrazovanja kod Srba. Srp Arh Celok Lek. 1994; 122(3-4): 123-5.

14. Pavlović BB. The Hilandar Medical Codex the most famous reminder of Serbian medieval medical science. Srp Arh Celok Lek. 1989; 117(7-8): 553-60.

15. Ilić-Tasić S, Ravinić D, Pantović M, Bojanić V, Pavlović B. Developmental conditions of medicine and spiritual culture at the time of grand Prince Stefan Nemanja. Srp Arh Celok Lek. 2012; 140(3-4): 250-4.
Brankovićeve dinastije), a takođe oslepljen usled opekotina oba oka. Čuvena nacionalna i istorijska ličnost je bio Filip Višnjić, slepi guslar i autentičan tvorac srpskih, narodnih tradicija, sa sekvelama obostranog infektivnog panuvetisa još kao dete.

Ključne reči: srpska istorija, slepe ličnosti, medicina, Stefan Dečanski, Stefan Branković, Filip Višnjić.

16. Divljanović D. Interesting medical motiv in the King's Church of the Studenica Monastery. Srp Arh Celok Lek. 1969; 97(1): 123-4

17. Katic R. Hospitals Middle Ages: the monastery hospital. U: Serbian medicine from IX to XIX century. Belgrade: Sanu, 1967: 299-311.

18. Pavlović B. Istorija srpske medicine. Beograd: Službeni list Publ, 2002.

19. Pavlović B. Manastirske bolnice u srednjovekovnoj Srbiji. Crkvene studije. 2004; 1(1): 381-8.

20. Obolenski D. Vizantijski komonvelt. Beograd: Prosveta Publ, 1996.

21. Janjevac P. Žitije cara Uroša. U: Milankov M. Stare srpske biografije. Beograd: Prosveta, 1975: 249-64.

22. Srejović D, Gavrilović S, Ćirković SM. Istorija srpskog naroda: Od najstarijih vremena do Maričke bitke (1371). Srpska književna zadruga Publ, 1993.

23. Miserachs García S, Castillo Campillo L. The repercussions of the ophthalmic wound of Philip II of Macedonia. Arch Soc Esp Oftalmol. 2010; 85(2): 85-7.

24. Elsie R. A Dictionary of Albanian Religion, Mythology, and Folk Culture. NYU Press Publ, 2001.

25. Jiriček K. Duhovni i društveni život u doba Nemanjića. U: Istorija Srba. Druga knjiga - Kulturna istorija. Beograd: Narodna knjiga, 1952: 252-318.

26. Dolezalova V. Knight's jousting tournaments and eye injuries. Cesk Slov Oftalmol. 2007; 63(2): 134-5.

27. Gagulić PV. Crkva sv. Panteleja u Nišu - zadužbina srpskog velikog župana Stevana Nemanje. U: Crkva svetog Pantelejmona u Nišu. Niš: Centar za crkvene studije, 2002: 30-4.

28. Nikolić N. Harmonija kratkih ogleda: Jovan Deretić, Etide iz stare srpske književnosti, Svetovi Novi Sad 2000. Novi Sad: Zbornik Matice srpske za književnost i jezik, 2002: 539-47.

29. Bogdanović D. Istorija stare srpske književnosti, Beograd: Publ, 1980.

30. Nestorović Z. Prikaz knjige. U: Ogledi iz srpske književnosti, Lompar M, društvo za srpski jezik i književnost Srbije, Beograd: Prilozi za KJIF 73, 2007: 209-14.

\section{Correspondence to / Autor za korespondenciju}

Katarina M. Janicijevic

Faculty of Medical Sciences, University of Kragujevac, Serbia

Svetozar Markovic 69, 34000 Kragujevac, Serbia

Tel: $+38134 / 369828$

Mob: +381642183797

E-mail:kaja.andreja@yahoo.com 